\title{
The Effect of Intercropping of Lablab (Lablab purpureus L.) and Cowpea (Vigna unguiculata L.) at Different Planting Densities on in vitro and in sacco Dry Matter Digestibility of Napier Grass (Pennisetum purpureum)
}

Negasu Gamachu Dinsa', Kassahun Desalegn Yalew²

10.18805/ag.DF-390

\begin{abstract}
Background: The advantage of intercropping is the more efficient utilization of the all available resources and the increased productivity compared with each sole crop of the mixture. If cowpea and Lablab intercropping with Napier grass its nutritional values was improved. Methods: The experimental design was factorial combination arrangement in randomized complete block design with three inter and intra spaces $(1 \mathrm{~m} \times 0.5 \mathrm{~m}, 0.75 \mathrm{~m} \times 0.5 \mathrm{~m}, 0.5 \mathrm{~m} \times 0.5 \mathrm{~m})$ and intercropping with two tropical legumes. Treatments were T1= Pure Napier grass at $1 \mathrm{~m}$ row spacing, T2= Napier grass intercropped with lablab at $0.75 \mathrm{~m}$ row spacing, T3= Napier grass intercropped with cowpea at $0.5 \mathrm{~m}$ row spacing, $\mathrm{T} 4=$ Napier grass intercropped with cowpea at $1 \mathrm{~m}$ row spacing, $\mathrm{T} 5=$ Napier grass intercropped with lablab at $0.5 \mathrm{~m}$ row spacing, T6= Pure Napier grass at $0.75 \mathrm{~m}$ row spacing, T7= Napier grass intercropped with lablab at $1 \mathrm{~m}$ row spacing, T8= Napier grass intercropped with cowpea at $0.75 \mathrm{~m}$ row spacing, T9= Pure Napier grass at $0.5 \mathrm{~m}$ row spacing and totally nine treatments were used. Soil samples were collected before and after forage harvested.

Result: Napier grass intercropped with lablab and cowpea at different planting densities had significant effect $(P<0.05)$ on the in vitro dry and organic matter digestibility (IVDMD, IVOMD) and increased digestibility. The OM degradation constant was significantly different $(P<0.05)$ but 'ED' was not and for DM degradation ' $c$ ' and ' $b$ ' were non-significant $(P>0.05)$ for Napier grass intercropped with lablab and cowpea at different planting densities. In conclusion, Napier grass intercropped with lablab and cowpea at a planting density of 24 plants $\mathrm{m}^{-2}$ was better choice for high yield and forage quality.
\end{abstract}

Key words: Cowpea, Lablab, Intercropping, Napier grass, Nutritive qualities, Dry matter and organic matter digestibility, In vitro, In saco.

\section{INTRODUCTION}

The principal advantage of intercropping is the more efficient utilization of the all available resources and the increased productivity compared with each sole crop of the mixture (Willey, 1979; Mucheru-Muna et al., 2010). Yield advantage occurs because growth resources such as light, water and nutrients are more efficiently absorbed and converted into crop biomass by the intercropping over time and space as a result of differences in competitive ability for growth resources between the component crops which exploit the variation of the mixed crops in characteristics such as rates of canopy development final canopy size (width and height) photosynthetic adaptation of canopies to irradiate conditions and rooting depth (Tsubo et al., 2001; Midmore, 1993).

Integration of legumes into forage production systems help smallholder farmers to produce more biomass forage and increase fodder production in quality and quantity which contributes to livestock directly (Tadesse et al., 2012). The reason of yield advantage of intercropping are mainly that environmental resources such as water, light and nutrients can be utilized more efficiently in intercropping than in the respective sole cropping systems (Liu et al., 2006). Therefore, the use of grass-legume forage intercropping helps to increase productivity of land and livestock feedstuffs.
1Oromia Agricultural Research Institute (IQQO), Haro Sabu Agricultural Research Centre, Haro Sabu, Oromia, Ethiopia.

${ }^{2}$ University of Gondar, Department of Animal Production and Extension, Gondar, Ethiopia.

Corresponding Author: Negasu Gamachu Dinsa, Oromia Agricultural Research Institute (IQQO), Haro Sabu Agricultural Research Centre, Haro Sabu, Oromia, Ethiopia.

Email: negasugamachu@gmail.com

How to cite this article: Dinsa, N.G. and Yalew, K.D. (2022). The Effect of Intercropping of Lablab (Lablab purpureus L.) and Cowpea (Vigna unguiculata L.) at Different Planting Densities on in vitro and in sacco Dry Matter Digestibility of Napier Grass (Pennisetum purpureum). Agricultural Science Digest. DOI: 10.18805/ag.DF-390.

Submitted: 30-07-2021 Accepted: 15-12-2021 Online: 16-01-2022

Napier grass is a perennial C4 grass species that is native to Sub-Saharan Africa from where it is believed to have been distributed to other tropical and subtropical regions around to world (Harris et al., 2010; Kandel et al., 2016). It has been reported to be adapted a wide range of soil conditions and agro-ecologies, from sea level to 2500 meters and it can offer strong resistance to dry spells, although it grows best in areas where the annual rainfall is between 750 and $2500 \mathrm{~mm}$ (Singh et al., 2013). It is a tall, 
The Effect of Intercropping of Lablab (Lablab purpureus L.) and Cowpea (Vigna unguiculata L.) at Different Planting...

stout and deep-rooted perennial bunch grass well known for its high yielding capability and mainly used for cut-andcarry feeding systems for livestock (Woodard and Prine, 1991; FAO, 2015).

The yield and nutritional values of Napier grass mainly depends on the type of cultivar used which in turn is influenced by both the environment and management practices employed (Oliveira et al., 2014). Napier grass yield has been reported around 60 tons/ha/year (Rengsirikul et al., 2013) and about 10 tons/ha/one cut cycle of DM (ILRI, $2010 \mathrm{~b})$. The nutritional value and other nutritional qualities of Napier grass have been reported across different studies and show significant variation in dry matter production (DM), crude protein (CP), neutral detergent fiber (NDF) and acid detergent fiber (ADF). However on average, Napier grass is considered to contain $9 \% \mathrm{CP}, 20 \% \mathrm{DM}, 70 \% \mathrm{NDF}, 50 \%$ ADF, $9 \%$ ash and $6 \%$ lignin in samples taken from 10-15 week old plants (Islam et al., 2003; Gwayumba et al., 2002).

Lablab is an ancient crop and has been documented by archaeo-botanical finds in India prior to 1500 BC (Fuller, 2003). Lablab (Lablab purpureus), formerly Dolichos lablab, also called Hyacinth bean, Egyptian bean and Fuji mame (in Japan) is a popular legume vegetable in Southern Asia, China, Japan, West Africa and the Caribbean (Valenzuela and Smith, 2002b). Furthermore, Morris, (2009) reviewed its bio-functional properties for use as pharmaceutical or nutraceutica.

Lablab is drought hardy and has been grown in arid, semi-arid and humid regions with rainfalls between 200 and $2500 \mathrm{~mm}$ (Hendricksen and Minson, 1985). It needs rainfall or irrigation (minimum of 10 to $20 \mathrm{~mm}$ ) during germination and early establishment, although once established it is extremely resistant to drought (Mayer et al., 1986). Being a hardy plant, lablab can be found throughout the tropics and subtropics; ranging from $30^{\circ}$ south to $30^{\circ}$ North Latitude. It is normally grown from sea level up to elevations ranging between 1800 and 2100 meters (Hendricksen and Minson, 1985; Mayer et al., 1986).

Similarly, cow pea plays an important nutritional role in the sub-Saharan areas because of high protein content in its grains and leaves (Pasquet and Fotso, 1994). Because of its superior nutritional attributes, versatility, adaptability and productivity cowpea was chosen by the United State National Aeronautical and Space Administration (NASA) as one of few crops worthy of study for cultivation in space stations (Ehlers and Hall, 1997). Grasses-legumes intercropping of Napier grass with legumes species improve the nutritive value of Napier grass (Mohammeda et al., 2016). However, there is a controversial idea about the planting densities on the biomass yield and nutritional value of Napier grass in different parts of the country.

Benefits of growing grass and legumes as mixed fodder crop are to maximize yield and quality in forage production (Yisehak, 2008). Mixed cropping especially with legumes can improve both forage quality and yield because legumes are good source of protein (Zhu et al., 2001). Furthermore, intercropping legumes with grasses significantly reduced neutral detergent fiber and acid detergent fiber content and increase digestibility of the forage.

Legumes have higher protein content than grasses and as a result the protein requirements of growing animals can be met to a large degree by adequate legumes in the forage mix. Legesse et al., 2012 found that alfalfa mixture with grass pasture contained more crude protein, compared to grass pasture. The DM yields of both the binary and ternary legume-grass mixtures were greater than the yield of any grass under mono-culture (Albayrak and Türk, 2013).

Significant effects of Napier Grass/ Lablab associations and their interactions were observed on crude protein yield (CPY), in vitro organic matter digestibility (IVOMD), content of $C P$, neutral detergent fiber (NDF), acid detergent fiber (ADF), acid detergent lignin (ADL), ash and hemicelluloses (Bayble et al., 2007). Association of Napier grass with Lablab species generally improved the nutritive value of Napier grass (Bayble et al., 2007). Therefore, to this effect Napier grass may get additional nutritive value from intercropping with Lablab. These indicated the possibility of improving the feeding of animals in tropical regions by planting Napier grass which is reputed for its high biomass yield along with lablab, thus enhancing the quality of nutrients supplied to animals (Bayble et al., 2007).

Intercropping of Napier grass with legumes species generally improve the nutritive value of Napier grass (Bayble et al., 2007). These indicated the possibility of improving the feeding of animals in tropical regions by planting Napier grass, which is reputed for its high biomass yield along with legumes such as cowpea and lablab, thus enhancing the quality of nutrients supplied to animals (Bayble et al., 2007). Plant densities or pattern intercropping has significant effect on dry matter production of the Napier grass.

Considering the above merits of Napier grass, lablab and cow pea intercropping evaluating the effect of these two forage legumes on the nutritive value of Napier grass will be of great importance. Information on the management practices and cropping system that influence yield quantity and nutritive quality of Napier grass when intercropped with lablab and cowpea at different planting densities was not well practiced in Ethiopia country (Mohammeda et al, 2016). Therefore the current study was being carried out with the objectives to determine the effect of inter-cropping lablab and cow pea on the nutritional qualities of Napier grass.

\section{MATERIALS AND METHODS Description of the study area}

The study was conducted at Haro Sabu Agricultural Research Center during the main cropping season (Fig 1). The center is located in western Ethiopia at $550 \mathrm{~km}$ from Addis Ababa. It lies at latitude of $8^{\circ} 52^{\prime} 51^{\prime \prime} \mathrm{N}$ and longitude $35^{\circ} 13^{\prime} 18^{\prime \prime} \mathrm{E}$ and altitude of 1515 m.a.s.l. It has a warm humid climate with average minimum and maximum temperature of 14 and $30^{\circ} \mathrm{C}$ respectively (HSARC, 2012). The area receives average annual rainfall of $1000 \mathrm{~mm}$ and its 
The Effect of Intercropping of Lablab (Lablab purpureus L.) and Cowpea (Vigna unguiculata L.) at Different Planting...

distribution pattern is uni-modal (HSARC, 2012) Table 1. The main rainy season covers from April to October. The soil type of the experimental site was vertisol with sandy loam in texture(Abebe, 2007). The area is characterized by coffee based farming and crop-livestock mixed farming system (HSARC, 2012).

\section{Experimental layout, design and treatments}

The experimental design was factorial combination arrangement in RCBD with three blocks consisting of three levels of inter and intra row spacing of Napier grass (ILRI
16840 accession ) i.e. $0.5 \mathrm{~m} \times 0.5 \mathrm{~m}, 0.75 \mathrm{~m} \times 0.5 \mathrm{~m}$ and 1 $\mathrm{m} \times 0.5 \mathrm{~m}$ intercropping with two tropical forage legumes of cowpea (Vigna unguiculata L.) Bole variety and Lablab (Lablab purpureus L.) 14455 accession between the rows of Napier grass and totally nine treatments were used (Table 2 ).

Total area of land $525 \mathrm{~m}^{2}(35 \mathrm{~m} \times 15 \mathrm{~m})$ was selected and thoroughly prepared for sowing. The land was ploughed and harrowed with a tractor and then hoe to make the soil fine. The land was divided in to three blocks and each of them has contained nine treatments. The plot size was $12 \mathrm{~m}^{2}$

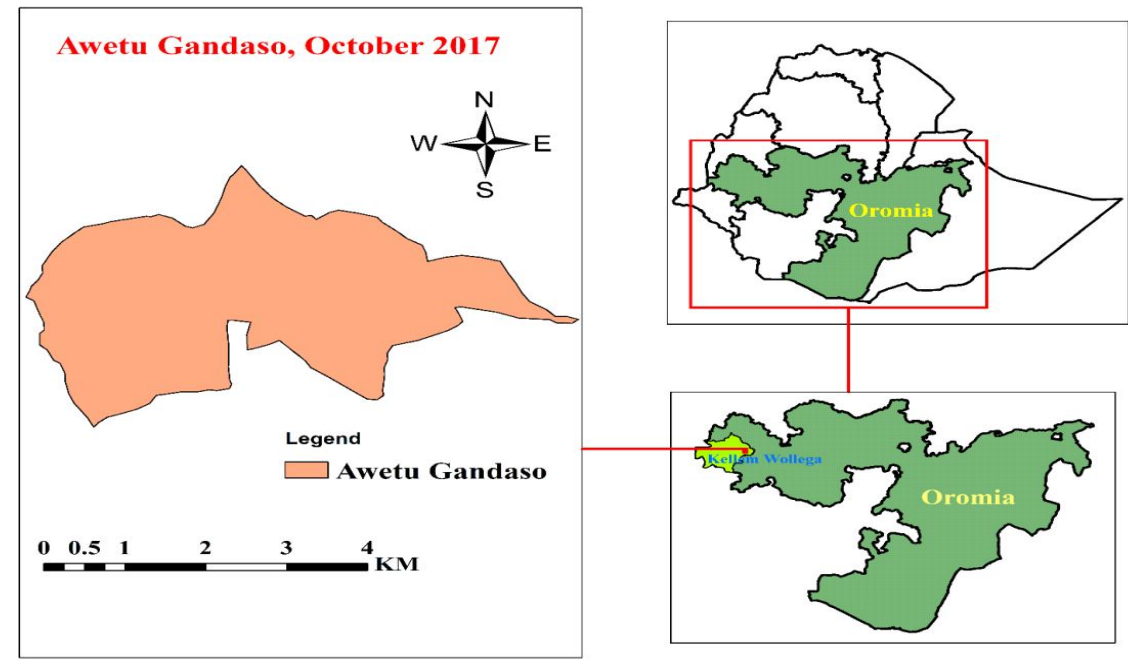

Fig 1: Map of the purposed study area.

Table 1: Agro-metrological data of the study area during 2017 at Haro Sabu Agricultural Research Center, Oromia, Ethiopia.

\begin{tabular}{|c|c|c|c|c|c|c|c|c|c|c|c|c|}
\hline \multirow{2}{*}{ Description } & \multirow[b]{2}{*}{ Jan } & \multicolumn{11}{|c|}{ Months of the year 2017} \\
\hline & & Feb & Mar & Apr & May & Jun & Jul & Aug & Sept & Oct & Nov & Dec \\
\hline $\mathrm{RF}(\mathrm{mm})$ & 0.0 & 17.6 & 16.2 & 158.2 & 248.7 & 180.1 & 291.5 & 307.1 & 223.2 & 117.8 & 33.1 & 0.4 \\
\hline $\mathrm{T}^{\circ} \mathrm{C}$ (Max.) & 33.0 & 32.9 & $X x$ & $X x$ & 27.4 & 27.2 & 24.6 & 25.2 & 26.1 & 26.7 & 27.3 & 29.7 \\
\hline $\mathrm{T}^{\circ} \mathrm{C}$ (Min.) & $X x$ & 8.8 & 14.5 & 15.7 & 14.6 & 11.6 & 11.4 & 11.3 & 11.2 & 10.9 & 10.5 & 10.3 \\
\hline $\mathrm{RH}(\%)$ & 37.2 & 54.5 & 45.3 & 58.3 & 66.9 & 69.0 & 77.2 & 73.8 & 74.7 & 77.5 & 72.7 & 53.7 \\
\hline
\end{tabular}

Remarks: Max. $=$ Maximum; Min. $=$ Minimum; $m m=$ Millimeter; $R F=$ mean rain fall; $\mathrm{RH}=$ Relative humidity; $\mathrm{T}^{\circ} \mathrm{C}=$ Mean temperature in degree celsius; $x x=$ Data not available. Source: Asosa Meteorological Agency (2017).

Table 2: Row spacing, plant spacing and intra row structure of the Napier grass during the experimental periods.

\begin{tabular}{lcccc}
\hline Treatments & Row spacing $(\mathrm{m})$ & Intercropped materials & Area/plant $\left(\mathrm{m}^{2}\right)$ & No. Napier grass/plot \\
\hline T1 & 1 & - & 0.5 & 24 \\
T2 & 0.75 & Lablab & 0.375 & 32 \\
T3 & 0.5 & Cowpea & 0.25 & 40 \\
T4 & 1 & Cowpea & 0.5 & 24 \\
T5 & 0.5 & Lablab & 0.25 & 40 \\
T6 & - & 0.375 & 32 \\
T7 & 1 & Lablab & 0.5 & 24 \\
T8 & 0.75 & Cowpea & 0.375 & 32 \\
T9 & 0.5 & - & 0.25 & 40
\end{tabular}

Where, $\mathrm{T} 1=$ Pure Napier grass at $1 \mathrm{~m}$ row spacing; $\mathrm{T} 2=$ Napier grass intercropped with lablab at $0.75 \mathrm{~m}$ row spacing; $\mathrm{T} 3=$ Napier grass intercropped with cowpea at $0.5 \mathrm{~m}$ row spacing; $\mathrm{T} 4=$ Napier grass intercropped with cowpea at $1 \mathrm{~m}$ row spacing; $\mathrm{T} 5=\mathrm{Napier}$ grass intercropped with lablab at $0.5 \mathrm{~m}$ row spacing; $\mathrm{T} 6=$ Pure Napier grass at $0.75 \mathrm{~m}$ row spacing; $T 7=$ Napier grass intercropped with lablab at $1 \mathrm{~m}$ row spacing; $\mathrm{T} 8=$ Napier grass intercropped with cowpea at $0.75 \mathrm{~m}$ row spacing; $\mathrm{T} 9=$ Pure Napier grass at $0.5 \mathrm{~m}$ row spacing. 
The Effect of Intercropping of Lablab (Lablab purpureus L.) and Cowpea (Vigna unguiculata L.) at Different Planting...

$(4 \mathrm{~m} \times 3 \mathrm{~m})$ and spacing between plot and between blocks was $1 \mathrm{~m}$ and $1.5 \mathrm{~m}$ respectively. Treatments were assigned to each plot within a block by SAS 9.3 version generated randomization code to each plot.

The Napier grass ILRI 16840 (Pennisetum purpureum) which was used as a parent plant material was cut into stems with a minimum of three nodes per cut for planting and was planted $15-20 \mathrm{~cm}$ deep at angle of about $30^{\circ}-45^{\circ}$ (Ansah et al., 2010) and the seed of $V$. unguiculata was drilled in between the rows of Napier grass at a seeding rate of 10 $\mathrm{kg} / \mathrm{ha}$ (Mullen et al., 2003) and L. purpureus was drilled in between the rows of Napier grass at a seeding rate of $8 \mathrm{~kg} /$ ha in $7-10 \mathrm{~cm}$ depth (ILRI, 2010b). Fertilizer was applied at the rate of $100 \mathrm{~kg} \mathrm{ha}^{-1}$ DAP during establishment for all experimental units. Weeding was done as early as possible to eliminate re-growth of undesirable plants and in order to promote fodder grass growth by increasing soil aeration the plots was kept weed free throughout growth period (Orodho, 2006). The field experiment was done for three months (90 days) at Haro Sabu Agricultural research center field experimental station. Then after in vitro and in sacco dry matter was done at Holeta Agricultural research center animal feed analytical laboratory for three months.

\section{Data collected}

\section{In vitro dry matter digestibility}

Chemical analysis was used performed on all for samples used in vitro dry matter digestibility (IVDMD). The two-stage rumen inoculates pepsin method of Tilley and Terry (1963) was used to determine IVDMD. Rumen liquor was collected from three rumen fistulated steers and transported to the laboratory using thermos flask that have been pre-warmed to $39^{\circ} \mathrm{C}$. Rumen liquor was taken in the morning before animals were offered feed. A duplicate sample $0.5 \mathrm{~g}$ each was incubated with $30 \mathrm{~mL}$ of rumen liquor in $100 \mathrm{ml}$ test tube in water bath at $39^{\circ} \mathrm{C}$ for a period of $48 \mathrm{~h}$ for microbial digestion followed by another $48 \mathrm{~h}$ for enzyme digestion with acid pepsin solution. Blank samples containing buffered rumen fluid were incubated in duplicates for adjustment. Drying of samples residues were done at $105^{\circ} \mathrm{C}$ for $24 \mathrm{~h}$. The samples were then ashed to estimate IVOMD. An IVOMD analysis was carried out at Holeta Agricultural research center animal feed analytical laboratory.

Metabolisable energy (ME) was calculated from IVOMD using the equation: $\mathrm{ME}\left(\mathrm{MJ} \mathrm{kg}{ }^{-1} \mathrm{DM}\right)=0.15^{*} \mathrm{IVOMD}$ (Pinkrton, 2005).

\section{In sacco digestibility}

In Sacco digestibility was carried out at Holeta Agricultural Research Center Animal Nutrition Analytical Laboratory. Composite samples of Napier grass for each treatment were taken and dried in a forced draft oven at $60^{\circ} \mathrm{C}$ for $72 \mathrm{~h}$. Samples were ground and passed through a $2 \mathrm{~mm}$ screen (mesh) using Wiley mill for in Sacco digestibility.

A numbered Nylon bag with $6.5 \times 14 \mathrm{~cm}^{2}$ dimension with a pore size of $41 \mathrm{~mm}$ was taken into an oven and dried at $60-65^{\circ} \mathrm{C}$ for 30 minutes. Contented was weighed immediately or after allowing to cool to room temperature in a desiccators and $3.0 \mathrm{~g}$ of dried forage samples were tightly packed using nylon string which is resistant to rumen micro-organisms and then taking in three rumen fistulated steers for $0,6,12$, 24, 48, 72 and $96 \mathrm{~h}$. Each feed sample was incubated in duplicate in the three steers for any one incubation time. At the end of each incubation hours, all the bags (including the zero hour samples) were immediately washed with cold water for about 30 minutes under running tap water while rubbing gently between thumb and fingers until the water runs clear and then the washed bags were dried in an oven at $60-65^{\circ} \mathrm{C}$ for about 48 hours. Duplicate bags of each sample were washed without incubating in the rumen in order to determine the washing loss. The dried bags were then taken out of the oven and allowed to cool down in desiccators and weigh immediately.

The digestibility or Disappearance of DM (DMD) and OM (OMD) of each incubation time were determined as (AOAC, 1990).

Disappearance $=\frac{(\mathrm{SWa}-\mathrm{BW}) \times \mathrm{DMa}-(\mathrm{SWb}-\mathrm{BW}) \times \mathrm{DMb}}{(\mathrm{SWa}-\mathrm{BW}) \times \mathrm{DMa}}$

Where,

$\mathrm{SWa}=$ Weight of the original sample + nylon bag.

$\mathrm{BW}=$ Weight of empty nylon bag.

$\mathrm{DMa}=$ Dry matter of feed sample.

$\mathrm{DMb}=$ Dry matter of residue sample.

$S W b=$ Weight of the sample + nylon bag after incubation.

The DMD and OMD values at various times of incubation are fitted to the exponential equation:

$$
p=a+b\left(1-e^{-c t}\right)
$$

Where

$a=$ washing loss (rapidly soluble fraction); $b=$ slowly degradable fraction and $c=$ the rate of degradation, $e=$ the natural logarithm, $p=$ the potential disappearance of DM / $\mathrm{OM}$ at time $\mathrm{t}$ and $\mathrm{t}=$ time as described by Ørskov et al. (1981) using the Neway Excel programme(Chen, 1995). The potential degradability (PD) was estimated as

$$
P D=a+b
$$

whereas the effective degradability of DM and OM (ED) was calculated using (Ørskov and McDonald, 1979) formula:

$E D=a+\left[\left(b^{*} c\right) /(c+k)\right]$ at $0.03 /$ hour for grass rumen out flow rate $(k)$. Where $a, b$ and $c$ are as described above and $k=$ passage rate.

\section{Statistical analysis}

Data were subjected to ANOVA procedure by using SAS software version 9.3 (Littell et al., 2002). Significant means were separated and compared using Least Significant Difference (LSD) test at $5 \%$ significant level. The analysis of variance model for the in Sacco degradability parameters were

Where,

$$
Y i j=\mu+T i+A i+e i j
$$

Yij = individual observation. 
$\mu=$ overall mean.

$\mathrm{Ti}=$ Treatment effect.

$\mathrm{Ai}=$ Animal effect.

$\mathrm{Eij}=$ residual error.

\section{RESULTS AND DISCUSSION} In vitro digestibility

\section{In vitro dry matter digestibility}

Napier grass at different planting densities intercropped with lablab and cowpea had significant effect $(P<0.05)$ on the in vitro dry matter digestibility (IVDMD) (Table 3 ). Napier grass intercropped with lablab (T7) and cowpea (T4) at spacing of $1 \mathrm{~m} \times 0.5 \mathrm{~m}$ has highest IVDMD with the mean result of $(64.85 \pm 1.99 \%)$ and $(66.92 \pm 0.66 \%)$ value, respectively while other mean comparisons were not significant $(P>0.05)$. On the other hand, sole Napier grass planted at plant spacing of $0.5 \mathrm{~m} \times 0.5 \mathrm{~m}$ (T9) had the lowest value of the IVDMD and IVDMD increased with wider spaces of Napier grass in the sole and intercropped at three different planting densities. The result noted by Bayble et al. (2007) for IVDMD of Napier grass at spacing of $1 \mathrm{~m} \times 0.5 \mathrm{~m}$ intercropped with lablab harvested at 90 days was $(68 \%)$ and it was higher than the mean result $(64.85 \pm 1.99 \%)$ for Napier grass at $1 \mathrm{~m} \times 0.5 \mathrm{~m}$ space intercropped with lablab of the present finding. Such variation could be associated with various factors like rain, humidity, light and temperature, soil fertility and other management practices have an influence on IVDMD of Napier grass (Assefa and Ledin, 2001).

The nutritive value of forages like voluntary feed intake, crude protein and structural carbohydrates and the digestibility of the grass could be improved when inclusion of associated legume with grass (Demissie Negash et al., 2017). Grass associated with legume inclusion might increase feed intake as the IVDMD and feed intake are positively correlated (Van Soest, 1994). The IVDMD value of Napier grass with different space intercropping by lablab and cowpea of the current study fits the digestibility of tropical grasses which lies between 50 to $60 \%$ (Owen and Jayasuriya, 1989).

\section{In vitro organic matter digestibility}

The effect of intercropping of Napier grass with lablab and cowpea at different plating densities on IVOMD was significant $(P<0.05)$. This is in line with the finding of (Mohammeda et al, 2016) who noted that Napier grass intercropped with lablab with different spaces or planting densities had significantly $(P<0.05)$ higher values of IVOMD than sole Napier grass. Mixing of Napier grass with lablab and cowpea improved the IVOMD of the Napier grass indicating that the feeding value of Napier grass can be enhanced in terms of nutrient content and digestibility. The IVOMD values of all the treatments were above the critical threshold level of $50 \%$ required for feeds to be considered as having acceptable digestibility (Owen and Jayasuriya, 1989).

The forages below this level of IVOMD content may result in reduced feed intake due to lower nutrient content and digestibility. The highest IVOMD value $(63.73 \% \pm 0.98)$ was recorded with Napier grass intercropped with lablab (T7) at $1 \mathrm{~m} \times 0.5 \mathrm{~m}$ space and the lowest value $(52.58 \pm 0.65 \%)$ was recorded from sole Napier grass planted at $0.5 \mathrm{~m} \times 0.5 \mathrm{~m}$ space without intercropped with legumes (T9) which was lower than the $67.96 \%$ noted by (Bayble

Table 3: Least square means and standard errors for In vitro dry matter (IVDMD), organic matter digestibility (IVOMD) and ME content of Napier grass.

\begin{tabular}{lccc}
\hline \multirow{2}{*}{ Treatments } & \multicolumn{3}{c}{ IVDMD and IVOMD percentage values (\%) } \\
\cline { 2 - 4 } & IVDMD (\%) & IVOMD (\%) & ME (MJ/kg) \\
\hline T1 & $55.75 \pm 1.74^{\mathrm{b}}$ & $56.86 \pm 2.29^{\text {cd }}$ & $8.53 \pm 0.34^{\text {cd }}$ \\
T2 & $57.64 \pm 1.06^{\mathrm{b}}$ & $58.20 \pm 1.58^{\mathrm{bcd}}$ & $8.73 \pm 0.23^{\mathrm{bcd}}$ \\
T3 & $62.22 \pm 0.82^{\mathrm{ab}}$ & $9.33 \pm 0.12^{\mathrm{a}} \mathrm{b}$ \\
T4 & $55.82 \pm 1.17^{\mathrm{b}}$ & $60.70 \pm 1.28^{\mathrm{abc}}$ & $9.33 \pm 0.19^{\mathrm{ab}}$ \\
T5 & $66.92 \pm 0.66^{\mathrm{a}}$ & $60.39 \pm 0.58^{\mathrm{abcd}}$ & $9.06 \pm 0.08^{\mathrm{abcd}}$ \\
T6 & $54.26 \pm 2.01^{\mathrm{b}}$ & $57.69 \pm 1.66^{\mathrm{cd}}$ & $8.65 \pm 0.25^{\text {cd }}$ \\
T7 & $53.99 \pm 0.90^{\mathrm{b}}$ & $63.73 \pm 0.98^{\mathrm{a}}$ & $9.56 \pm 0.14^{\mathrm{a}}$ \\
T8 & $64.85 \pm 1.99^{\mathrm{a}}$ & $56.35 \pm 2.16^{\mathrm{de}}$ & $8.45 \pm 0.32^{\mathrm{de}}$ \\
T9 & $56.77 \pm 1.54^{\mathrm{b}}$ & $52.58 \pm 0.65^{\mathrm{e}}$ & $7.88 \pm 0.09^{\mathrm{e}}$ \\
Mean & $53.03 \pm 1.87^{\mathrm{b}}$ & 58.75 & 8.81 \\
$P$-value & 57.67 & 0.0012 & 0.0012 \\
\hline
\end{tabular}

a, b, c, d, e Means in a columns, values followed by different letters differ significantly $(P<0.05) ; T 1=$ Pure Napier grass at $1 \mathrm{~m}$ row spacing, $\mathrm{T} 2=$ Napier grass intercropped with lablab at $0.75 \mathrm{~m}$ row spacing, $\mathrm{T} 3=$ Napier grass intercropped with cowpea at $0.5 \mathrm{~m}$ row spacing, $\mathrm{T} 4=$ Napier grass intercropped with cowpea at $1 \mathrm{~m}$ row spacing, T5= Napier grass intercropped with lablab at $0.5 \mathrm{~m}$ row spacing, T6= Pure Napier grass at $0.75 \mathrm{~m}$ row spacing, $T 7=$ Napier grass intercropped with lablab at $1 \mathrm{~m}$ row spacing, $\mathrm{T} 8=$ Napier grass intercropped with cowpea at $0.75 \mathrm{~m}$ row spacing, $\mathrm{T} 9=$ Pure Napier grass at $0.5 \mathrm{~m}$ row spacing, IVDMD $=$ In vitro dry matter digestibility, IVOMD $=$ In vitro organic matter digestibility, $\mathrm{kg}=$ kilo gram, $\mathrm{ME}=$ Metabolizable Energy, $\mathrm{MJ}=$ MegaJoul. 
The Effect of Intercropping of Lablab (Lablab purpureus L.) and Cowpea (Vigna unguiculata L.) at Different Planting...

et al., 2007) at ninety days of harvesting. Such variation might be due to a number of factors like climate, season, weather, soil type and fertility, soil moisture, physiological and morphological characteristics and these factors may vary with annuals versus perennials, grasses versus legumes, etc.(Kilcher, 1981). These factors bring rate of change in nutrient composition and digestibility with advancing plant development and maturity stages. Generally, IVOMD increased at wider spaces of Napier grass planted with lablab and cowpea than in the sole Napier grass planted.

\section{Metabolizable energy}

Since the ME was calculated from IVOMD values in this study, the ME content took a similar trend like that of IVOMD and generally increased with increasing proportion of legumes in the mixture. Metabolizable energy of all treatments were above the critical threshold level of 7.5 (MJ $\mathrm{kg}^{-1} \mathrm{DM}$ ) for roughages and forages as noted by Owen and Jayasuriya (1989).

\section{In sacco digestibility}

\section{In sacco DM disappearances and rumen degradability} characteristics

Analysis of variance show that there was a significant effect $(P<0.05)$ of Napier grass intercropping with lablab and cowpea at different planting densities on the in sacco dry matter disappearances (INDMD) at 12 and $72 \mathrm{~h}$ of incubation time (Table 4). Across all incubation periods (Table 4) there was similar trend in variation of the incubation hours between Napier grass intercropped with two legumes and Napier grass planted alone at different planting densities. Napier grass intercropped with lablab at $1 \mathrm{~m} \times$ $0.5 \mathrm{~m}$ spaces (T7) had higher disappearance percent value when compared with Napier grass grown alone at the same space (T6) and similar trend with Napier grass intercropped with lablab at $0.5 \mathrm{~m} \times 0.5 \mathrm{~m}$ (T5) was quick degraded than Napier grass grown alone at the same space (T9) at 12, 96 and $48 \mathrm{~h}$ of incubation respectively. Napier grass intercropped with lablab with $0.75 \mathrm{~m} \times 0.5 \mathrm{~m}$ (T2) had quick disappearance than Napier grass grown alone with the same space (T6) at $48 \mathrm{~h}$ of incubation. This was in agreement with (Mohammeda et al., 2016) who noted that Interaction of intercropping and spacing has a significant effect on in sacco DM disappearance at 12 and $48 \mathrm{~h}$ of incubation times $(\mathrm{P}<0.05)$. Generally the DM disappearance was higher in Napier grass intercropped with lablab than alone.

Napier grass intercropping with cowpea (i.e. T3, T4 and T8) at three different planting densities had disappearance more than Napier grass grown alone at the same planting densities (i.e. T1, T6 and T9) at $72 \mathrm{~h}$ of incubation. In sacco DM recorded at 48 hours incubation period was highest in Napier grass intercropping with lablab and cowpea and the lowest value was recorded in Napier grass planted alone at three planting densities because 48 hours of incubation time is considered as good measurement of in sacco DM disappearance in the animal digestive system. Generally, from 12 to $96 \mathrm{~h}$ of incubation, the in sacco DM disappearance also increased. This is similar to the result reported by (Klopfenstein et al., 2001a) who reported that in sacco DM disappearance increase with time incubation hours.

In general, effect of intercropping Napier grass with lablab and cowpea at different plants densities was significant for DM disappearances across the incubation time for 12 and $72 \mathrm{~h}$ incubation. The greatest DM disappearance at $12 \mathrm{~h}$ incubation was recorded in Napier grass intercropped with cowpea (T4) at $1 \mathrm{~m} \times 0.5 \mathrm{~m}$ space $(40.00 \pm 1.64 \%)$ followed by Napier grass intercropped with lablab (T5) at $0.5 \mathrm{~m} \times 0.5 \mathrm{~m}$ space $(38.09 \pm 1.75)$ and Napier grass intercropped with lablab $(\mathrm{T} 7)$ at $1 \mathrm{~m} \times 0.5 \mathrm{~m}$ space

Table 4: Least square means and standard errors for In sacco DM disappearances of Napier grass.

\begin{tabular}{|c|c|c|c|c|c|c|}
\hline \multirow{2}{*}{ Treatments } & \multicolumn{6}{|c|}{ In sacco DM disappearances (\%) at Rumen incubation time (hr) } \\
\hline & 6 & 12 & 24 & 48 & 72 & 96 \\
\hline $\mathrm{T} 1$ & $21.68 \pm 1.17$ & $33.41 \pm 0.72^{\mathrm{bc}}$ & $43.08 \pm 4.63$ & $66.77 \pm 2.35$ & $72.02 \pm 0.14^{\mathrm{bcd}}$ & $82.77 \pm 0.47$ \\
\hline $\mathrm{T} 2$ & $23.22 \pm 0.67$ & $37.23 \pm 1.84^{\mathrm{ab}}$ & $45.27 \pm 2.50$ & $71.60 \pm 0.58$ & $73.84 \pm 0.68^{\mathrm{abc}}$ & $83.74 \pm 0.50$ \\
\hline T3 & $23.50 \pm 1.10$ & $37.87 \pm 0.47^{\mathrm{ab}}$ & $43.34 \pm 0.26$ & $68.16 \pm 2.43$ & $71.68 \pm 0.71^{\mathrm{cd}}$ & $85.04 \pm 1.17$ \\
\hline $\mathrm{T} 4$ & $21.11 \pm 1.07$ & $40.00 \pm 1.64^{\mathrm{a}}$ & $43.93 \pm 0.74$ & $70.87 \pm 1.78$ & $72.96 \pm 0.86^{\mathrm{abc}}$ & $84.40 \pm 0.90$ \\
\hline T5 & $21.47 \pm 0.89$ & $38.09 \pm 1.75^{\mathrm{a}}$ & $45.35 \pm 0.61$ & $72.03 \pm 1.57$ & $72.30 \pm 1.25^{\mathrm{bcd}}$ & $83.50 \pm 0.92$ \\
\hline T6 & $20.98 \pm 0.66$ & $32.37 \pm 1.80^{c}$ & $42.94 \pm 0.66$ & $67.73 \pm 0.45$ & $70.40 \pm 1.17^{d}$ & $81.81 \pm 0.44$ \\
\hline $\mathrm{T} 7$ & $23.80 \pm 0.24$ & $38.36 \pm 0.84^{a}$ & $46.13 \pm 1.07$ & $70.61 \pm 0.71$ & $74.88 \pm 1.066^{a}$ & $85.28 \pm 1.28$ \\
\hline $\mathrm{T} 8$ & $22.99 \pm 1.58$ & $36.50 \pm 1.77^{a b c}$ & $44.42 \pm 0.70$ & $69.05 \pm 1.02$ & $74.16 \pm 1.28^{a b}$ & $84.26 \pm 0.24$ \\
\hline T9 & $21.70 \pm 1.18$ & $36.30 \pm 0.82^{a b c}$ & $42.81 \pm 0.23$ & $66.84 \pm 1.43$ & $70.57 \pm 1.07^{d}$ & $82.82 \pm 1.38$ \\
\hline Mean & 22.27 & 36.68 & 44.14 & 69.29 & 72.54 & 83.74 \\
\hline$P$ - value & 0.387 & 0.051 & 0.855 & 0.144 & 0.005 & 0.160 \\
\hline
\end{tabular}

a, b c d means in a columns, values followed by different letters differ significantly $(P<0.05)$, hr = hour; DM = dry matter, T1= Pure Napier grass at $1 \mathrm{~m}$ row spacing, T2= Napier grass intercropped with lablab at $0.75 \mathrm{~m}$ row spacing, T3= Napier grass intercropped with cowpea at $0.5 \mathrm{~m}$ row spacing, T4= Napier grass intercropped with cowpea at $1 \mathrm{~m}$ row spacing, T5= Napier grass intercropped with lablab at $0.5 \mathrm{~m}$ row spacing, T6= Pure Napier grass at $0.75 \mathrm{~m}$ row spacing, T7= Napier grass intercropped with lablab at $1 \mathrm{~m}$ row spacing, $\mathrm{T} 8=\mathrm{Napier}$ grass intercropped with cowpea at $0.75 \mathrm{~m}$ row spacing, $\mathrm{T} 9=$ Pure Napier grass at $0.5 \mathrm{~m}$ row spacing. 
The Effect of Intercropping of Lablab (Lablab purpureus L.) and Cowpea (Vigna unguiculata L.) at Different Planting...

$(38.36 \pm 0.84 \%)$, whereas the lowest DM disappearance at 12-hour incubation was recorded from Napier grass at $0.75 \mathrm{~m}$ $\times 0.5 \mathrm{~m}$ space without intercrop (T6) $(32.37 \pm 1.80 \%)$ followed by Napier grass $1 \mathrm{~m} \times 0.5 \mathrm{~m}$ space without intercrop (T1) $(33.41 \pm 0.72 \%)$ and Napier grass with $0.5 \mathrm{~m} \times 0.5 \mathrm{~m}$ space without intercrop (T9) $(36.30 \pm 1.77 \%)$. Napier grass intercropped with lablab (T7) at $1 \mathrm{~m} \times 0.5 \mathrm{~m}$ space showed the greatest DM disappearances at 72 and $96 \mathrm{~h}$ incubation in contrast to the rest of the treatments $(P<0.05)$.

Yet at a 48-h incubation, the Napier grass intercropped with lablab (T5) at $0.5 \mathrm{~m} \times 0.5 \mathrm{~m}$ space had the greatest DM disappearances $(72.03 \pm 1.57 \%)$ followed by Napier grass intercropped with lablab (T2) at $0.75 \mathrm{~m} \times 0.5 \mathrm{~m}$ space $(71.60 \pm 0.58 \%)$ and the least value of DM disappearances of Napier grass at $1 \mathrm{~m} \times 0.5 \mathrm{~m}$ spaces without intercropping (T1) $(66.77 \pm 2.35 \%)$ and Napier grass at $0.5 \mathrm{~m} \times 0.5 \mathrm{~m}$ space planted without intercropping (T9) $(66.84 \pm 1.43 \%)$.

Generally, the highest in Sacco DMD was recorded at $96 \mathrm{~h}$ incubation period and the lowest value was obtained at 6 hours incubation period in all treatments in the present study. This is similar to the result reported by Klopfenstein et al. (2001b) who indicated that the period of incubation period increases from 0 to 96 hours in the rumen and the in sacco DM degradability also increases.

Analysis of variance showed that there was a significant effect $(P<0.05)$ of Napier grass intercropped with lablab and cowpea at different planting densities on the Rumen DM disappearances characteristics of Napier grass at $k=0.03$ per hour of rumen fractional outflow rates for all treatments except for the slowly degradable fraction and rate of degradation(c) (Table 5). The greatest washing loss (a) of Napier grass was recorded in Napier grass intercropped with cowpea and lablab (T4 and T7) at $1 \mathrm{~m} \times 0.5 \mathrm{~m}$ space while the least value recorded was in the Napier grass planted at $1 \mathrm{~m} \times 0.5 \mathrm{~m}$ space without intercropping (T1). For potential degradability (PD) the highest value was recorded in Napier grass intercropped with lablab (T7) at 1 $\mathrm{m} \times 0.5 \mathrm{~m}$ space while in the Napier grass planted with 0.5 $\mathrm{m} \times 0.5 \mathrm{~m}$ space without intercropping (T9) recorded the least value $(\mathrm{P}<0.05)$.

The highest effective degradability $(E D)$ value was recorded in Napier grass intercropped with lablab (T7) at 1 $\mathrm{m} \times 0.5 \mathrm{~m}$ space followed Napier grass intercropped with cowpea (T4) at $1 \mathrm{~m} \times 0.5 \mathrm{~m}$ space and the least value was recorded in Napier grass planted at $0.75 \mathrm{~m} \times 0.5 \mathrm{~m}$ space without legumes intercropping (T6). Napier grass intercropping with lablab has higher Rumen DM degradability characteristics when compared with Napier grass planted alone at different planting densities. This was in agreement with (Njoka-Njiru et al., 2006a) who noted that washing loss and effective degradability were significantly higher in the intercropped Napier grass than the sole Napier grass. Napier grass intercropping with cowpea at three different planting densities was higher than Napier grass grown alone with the same space by rapid soluble fractions (wash losing).

In sacco OM disappearances and rumen degradability characteristics

Analysis of variance showed that there was a significant effect $(\mathrm{P}<0.05)$ of Napier grass intercropping with lablab and cowpea at different planting densities on in sacco organic matter disappearances (OMD) at 6,48 and 96 h of incubation time but No significant differences $(P>0.05)$ were observed at the rest of hours of incubation time (Table 6).

Napier grass intercropped with lablab at $0.75 \mathrm{~m} \times 0.5 \mathrm{~m}$ spaces (T2) had the greatest OM disappearances when compared with Napier grass grown alone planted with the same space (T6) at $6 \mathrm{~h}$ incubation and Napier grass

Table 5: Least square means and standard errors for In sacco dry matter rumen degradability characteristics.

\begin{tabular}{|c|c|c|c|c|c|}
\hline \multirow{2}{*}{ Treatments } & \multicolumn{5}{|c|}{ Rumen degradability characteristics } \\
\hline & a & $B$ & $\mathrm{PD}(a+b)$ & $c$ & $\mathrm{ED}(\mathrm{kp}=0.03)$ \\
\hline T1 & $7.09 \pm 0.93^{f}$ & $77.66 \pm 3.93$ & $84.75 \pm 4.75^{\mathrm{ab}}$ & $0.0343 \pm 0.007$ & $47.23 \pm 1.88^{\mathrm{bcd}}$ \\
\hline T2 & $10.56 \pm 0.31^{\mathrm{cd}}$ & $75.86 \pm 1.63$ & $86.42 \pm 1.90^{\mathrm{ab}}$ & $0.0303 \pm 0.002$ & $48.45 \pm 0.72^{\mathrm{ab}}$ \\
\hline T3 & $12.88 \pm 0.82^{\mathrm{b}}$ & $76.96 \pm 2.34$ & $89.85 \pm 2.71^{\mathrm{ab}}$ & $0.0247 \pm 0.002$ & $47.39 \pm 0.34^{\mathrm{abcd}}$ \\
\hline $\mathrm{T} 4$ & $14.42 \pm 0.23^{a}$ & $75.23 \pm 1.49$ & $89.64 \pm 1.31^{\mathrm{ab}}$ & $0.0251 \pm 0.001$ & $48.57 \pm 0.91^{\mathrm{ab}}$ \\
\hline T5 & $11.26 \pm 0.44^{c}$ & $74.94 \pm 1.01$ & $86.20 \pm 0.56^{\mathrm{ab}}$ & $0.0290 \pm 0.000$ & $48.07 \pm 0.56^{\mathrm{abc}}$ \\
\hline T6 & $8.59 \pm 0.41^{\mathrm{de}}$ & $76.43 \pm 1.69$ & $85.03 \pm 1.29^{\mathrm{ab}}$ & $0.0277 \pm 0.001$ & $45.26 \pm 0.44^{d}$ \\
\hline T7 & $15.29 \pm 0.10^{\mathrm{a}}$ & $76.10 \pm 3.29$ & $91.39 \pm 3.39^{a}$ & $0.0248 \pm 0.002$ & $49.42 \pm 0.22^{\mathrm{a}}$ \\
\hline T8 & $9.75 \pm 0.70^{\mathrm{de}}$ & $77.36 \pm 1.43$ & $87.11 \pm 0.84^{\mathrm{ab}}$ & $0.0286 \pm 0.000$ & $47.51 \pm 0.02^{\mathrm{abcd}}$ \\
\hline T9 & $8.36 \pm 0.16^{\mathrm{ef}}$ & $75.66 \pm 0.71$ & $84.03 \pm 0.58^{b}$ & $0.0294 \pm 0.001$ & $45.85 \pm 0.56^{c d}$ \\
\hline Mean & 10.92 & 76.25 & 87.16 & 0.02824 & 47.50 \\
\hline$P$-value & $<.0001$ & 0.989 & 0.036 & 0.404 & 0.032 \\
\hline
\end{tabular}

a, bcdef Means in a columns, values followed by different letters differ significantly $(P<0.05)$, a= washing loss (rapidly soluble fraction), $b=$ slowly degradable fraction, $c=$ the rate of degradation, ED= Effective Degradability, $P D=$ Potential Degradability, $11=$ Pure Napier grass at $1 \mathrm{~m}$ row spacing, T2= Napier grass intercropped with lablab at $0.75 \mathrm{~m}$ row spacing, T3= Napier grass intercropped with cowpea at 0.5 $\mathrm{m}$ row spacing, T4= Napier grass intercropped with cowpea at $1 \mathrm{~m}$ row spacing, T5= Napier grass intercropped with lablab at $0.5 \mathrm{~m}$ row spacing, T6= Pure Napier grass at $0.75 \mathrm{~m}$ row spacing, $\mathrm{T} 7=$ Napier grass intercropped with lablab at $1 \mathrm{~m}$ row spacing, $\mathrm{T} 8=\mathrm{Napier}$ grass intercropped with cowpea at $0.75 \mathrm{~m}$ row spacing, $\mathrm{T} 9=$ Pure Napier grass at $0.5 \mathrm{~m}$ row spacing. 
The Effect of Intercropping of Lablab (Lablab purpureus L.) and Cowpea (Vigna unguiculata L.) at Different Planting...

intercropped with lablab at $0.5 \mathrm{~m} \times 0.5 \mathrm{~m}$ (T5), Napier grass intercropped with lablab with $1 \mathrm{~m} \times 0.5 \mathrm{~m}$ (T7) showed similar OM disappearances value with Napier grass planted alone with the same space (T9) and (T1) at $6 \mathrm{~h}$ incubation.

Napier grass intercropped with lablab at different planting densities had no difference disappearance per cent value than Napier grass planted alone with the same space at $48 \mathrm{~h}$ incubation. This result disagrees with Mohammeda et al. (2016) who noted that interaction of intercropping and spacing had a significant effect on in sacco OM degradability at $48 \mathrm{~h}$ incubation times $(P<0.05)$. Nevertheless, improvement in the in sacco OM disappearances of Napier grass with three different spaces intercropped with lablab were higher than Napier grass planted without intercropping.

Napier grass intercropped with cowpea (T3) at $0.5 \mathrm{~m} \times$ $0.5 \mathrm{~m}$ space had higher degradability than Napier grass grown alone with the same space at 96 hours of incubation while decreased in the rest of an incubation hours. Napier grass intercropping with cowpea (T4) at $1 \mathrm{~m} \times 0.5 \mathrm{~m}$ space had the higher disappearance percent than Napier grass grown alone with the same space at $96 \mathrm{~h}$ incubation 6 and $96 \mathrm{~h}$ incubation. Napier grass intercropping with cowpea (T8) at $0.75 \mathrm{~m} \times 0.5 \mathrm{~m}$ space had the highest degradability than at $48 \mathrm{hrs}$ and no difference has been observed the in

Table 6: Least square means and standard errors for In sacco OM disappearances for Napier grass.

\begin{tabular}{lcccccc}
\hline \multirow{2}{*}{ Treatments } & \multicolumn{5}{c}{ In sacco OM disappearances $(\%)$ at Rumen incubation time (hr) } \\
\cline { 2 - 7 } & 6 & 12 & 24 & 48 & 72 & 96 \\
\hline T1 & $21.24 \pm 0.67^{\mathrm{bcd}}$ & $32.18 \pm 1.09^{\mathrm{a}}$ & $41.79 \pm 1.64$ & $68.30 \pm 2.08^{\mathrm{ab}}$ & $74.21 \pm 1.32$ & $76.00 \pm 0.3^{\mathrm{a}}$ \\
T2 & $23.74 \pm 0.58^{\mathrm{a}}$ & $29.53 \pm 1.29^{\mathrm{ab}}$ & $42.61 \pm 1.54$ & $69.03 \pm 1.22^{\mathrm{ab}}$ & $73.65 \pm 2.46$ & $78.98 \pm 0.9^{\mathrm{abc}}$ \\
T3 & $22.74 \pm 0.56^{\mathrm{ab}}$ & $28.19 \pm 0.68^{\mathrm{b}}$ & $37.93 \pm 0.18$ & $67.77 \pm 1.31^{\mathrm{ab}}$ & $76.46 \pm 0.85$ & $79.36 \pm 0.42^{\mathrm{ab}}$ \\
T4 & $23.65 \pm 1.18^{\mathrm{a}}$ & $29.64 \pm 0.80^{\mathrm{ab}}$ & $40.41 \pm 2.44$ & $70.45 \pm 2.76^{\mathrm{ab}}$ & $74.91 \pm 0.11$ & $80.07 \pm 0.18^{\mathrm{a}}$ \\
T5 & $22.39 \pm 0.17^{\mathrm{abc}}$ & $29.09 \pm 1.98^{\mathrm{b}}$ & $41.46 \pm 2.58$ & $71.51 \pm 0.42^{\mathrm{ab}}$ & $74.49 \pm 0.89$ & $80.23 \pm 0.95^{\mathrm{a}}$ \\
T6 & $20.25 \pm 0.12^{\mathrm{d}}$ & $30.41 \pm 0.82^{\mathrm{ab}}$ & $39.79 \pm 1.04$ & $68.93 \pm 0.92^{\mathrm{ab}}$ & $73.97 \pm 1.39$ & $77.36 \pm 0.80^{\mathrm{bcd}}$ \\
T7 & $20.41 \pm 0.17^{\mathrm{cd}}$ & $28.48 \pm 1.59^{\mathrm{b}}$ & $43.83 \pm 1.42$ & $70.23 \pm 1.05^{\mathrm{ab}}$ & $76.28 \pm 0.67$ & $79.80 \pm 1.42^{\mathrm{ab}}$ \\
T8 & $21.35 \pm 1.17^{\mathrm{bcd}}$ & $30.71 \pm 1.70^{\mathrm{ab}}$ & $42.28 \pm 0.84$ & $72.18 \pm 0.21^{\mathrm{a}}$ & $73.49 \pm 3.04$ & $78.27 \pm 0.39^{\mathrm{abcd}}$ \\
T9 & $22.11 \pm 0.46^{\mathrm{abc}}$ & $30.67 \pm 1.68^{\mathrm{ab}}$ & $40.38 \pm 1.11$ & $67.39 \pm 1.59^{\mathrm{b}}$ & $73.66 \pm 0.98$ & $76.79 \pm 0.84^{\mathrm{cd}}$ \\
Mean & 21.98 & 29.88 & 41.16 & 69.53 & 74.59 & 78.54 \\
$P$-value & 0.016 & 0.151 & 0.284 & 0.044 & 0.804 & 0.016 \\
\hline
\end{tabular}

${ }^{\mathrm{a}, \mathrm{b}}$ Means in a columns, values followed by different letters differ significantly $(P<0.05), \mathrm{hr}=$ Hour, $\mathrm{OM}=$ organic matter, $\mathrm{T} 1=\mathrm{Pure}$ Napier grass at $1 \mathrm{~m}$ row spacing, $\mathrm{T} 2=$ Napier grass intercropped with lablab at $0.75 \mathrm{~m}$ row spacing, $\mathrm{T} 3=$ Napier grass intercropped with cowpea at $0.5 \mathrm{~m}$ row spacing, $\mathrm{T} 4=$ Napier grass intercropped with cowpea at $1 \mathrm{~m}$ row spacing, $\mathrm{T} 5=$ Napier grass intercropped with lablab at $0.5 \mathrm{~m}$ row spacing, T6= Pure Napier grass at $0.75 \mathrm{~m}$ row spacing, $\mathrm{T} 7=$ Napier grass intercropped with lablab at $1 \mathrm{~m}$ row spacing, T8= Napier grass intercropped with cowpea at $0.75 \mathrm{~m}$ row spacing, $\mathrm{T} 9=$ Pure Napier grass at $0.5 \mathrm{~m}$ row spacing.

Table 7: Least square means and standard errors for In sacco Organic matter rumen degradability characteristics.

\begin{tabular}{lccccc}
\hline \multirow{2}{*}{ Treatments } & \multicolumn{5}{c}{ Rumen degradability characteristics } \\
\cline { 2 - 6 } & $a$ & $b$ & PD $(a+b)$ & $c$ & ED $(k p=0.03)$ \\
\hline T1 & $12.69 \pm 0.08^{\mathrm{ab}}$ & $71.81 \pm 0.14^{\mathrm{d}}$ & $84.50 \pm 0.18^{\mathrm{d}}$ & $0.0257 \pm 0.001^{\mathrm{a}}$ & $45.85 \pm 0.86$ \\
T2 & $13.78 \pm 1.54^{\mathrm{a}}$ & $75.14 \pm 1.68^{\mathrm{bcd}}$ & $88.92 \pm 1.46^{\mathrm{bcd}}$ & $0.0229 \pm 0.002^{\mathrm{ab}}$ & $46.27 \pm 0.67$ \\
T3 & $13.95 \pm 0.49^{\mathrm{a}}$ & $83.21 \pm 1.55^{\mathrm{a}}$ & $97.15 \pm 1.89^{\mathrm{a}}$ & $0.0182 \pm 0.001^{\mathrm{b}}$ & $45.23 \pm 0.38$ \\
T4 & $13.17 \pm 0.64^{\mathrm{ab}}$ & $79.34 \pm 3.93^{\mathrm{ab}}$ & $92.50 \pm 3.72^{\mathrm{ab}}$ & $0.0220 \pm 0.002^{\mathrm{ab}}$ & $46.25 \pm 1.21$ \\
T5 & $12.36 \pm 0.40^{\mathrm{ab}}$ & $78.51 \pm 3.52^{\mathrm{abc}}$ & $90.86 \pm 3.61^{\mathrm{bc}}$ & $0.0233 \pm 0.002^{\mathrm{a}}$ & $46.32 \pm 0.35$ \\
T6 & $12.01 \pm 0.56^{\mathrm{ab}}$ & $75.63 \pm 0.92^{\mathrm{bcd}}$ & $87.63 \pm 0.40^{\mathrm{bcd}}$ & $0.0234 \pm 0.000^{\mathrm{a}}$ & $45.14 \pm 0.16$ \\
T7 & $11.53 \pm 0.38^{\mathrm{b}}$ & $78.39 \pm 1.148^{\mathrm{abc}}$ & $89.92 \pm 1.52^{\mathrm{bcd}}$ & $0.0241 \pm 0.001^{\mathrm{a}}$ & $46.37 \pm 0.16$ \\
T8 & $11.28 \pm 0.42^{\mathrm{b}}$ & $75.22 \pm 0.11^{\mathrm{bcd}}$ & $86.505 \pm 0.53^{\mathrm{cd}}$ & $0.0261 \pm 0.000^{\mathrm{a}}$ & $46.25 \pm 0.81$ \\
T9 & $13.89 \pm 0.41^{\mathrm{a}}$ & $73.86 \pm 0.76^{\mathrm{d}}$ & $87.75 \pm 0.55^{\mathrm{bcd}}$ & $0.0224 \pm 0.001^{\mathrm{ab}}$ & $45.37 \pm 0.98$ \\
Mean & 12.74 & 76.79 & 89.53 & 0.0231 & 45.89 \\
$P$-value & 0.050 & 0.014 & 0.009 & 0.0310 & 0.865 \\
\hline
\end{tabular}

a, b c Means in a columns, values followed by different letters differ significantly $(P<0.05), a=$ washing loss (rapidly soluble fraction), $b=$ Slowly degradable fraction; $c=$ The rate of degradation, $D M D=$ Dry matter degradability; $E D=$ Effective degradability; $P D=P o t e n t i a l$ degradability, $\mathrm{T} 1=$ Pure Napier grass at $1 \mathrm{~m}$ row spacing, $\mathrm{T} 2=$ Napier grass intercropped with lablab at $0.75 \mathrm{~m}$ row spacing, $\mathrm{T} 3=\mathrm{Napier}$ grass intercropped with cowpea at $0.5 \mathrm{~m}$ row spacing, $\mathrm{T} 4=$ Napier grass intercropped with cowpea at $1 \mathrm{~m}$ row spacing, T5= Napier grass intercropped with lablab at $0.5 \mathrm{~m}$ row spacing, $\mathrm{T} 6=$ Pure Napier grass at $0.75 \mathrm{~m}$ row spacing, $T 7=$ Napier grass intercropped with lablab at $1 \mathrm{~m}$ row. 
The Effect of Intercropping of Lablab (Lablab purpureus L.) and Cowpea (Vigna unguiculata L.) at Different Planting...

the rest the treatments. This was in agreement with (NjokaNjiru et al., 2006a) who noted that OM disappearance at $48 \mathrm{~h}$ of incubation was significantly higher for intercropped Napier grass than sole Napier grass. Generally, the extent of digestion of Napier grass when intercropped with lablab and cowpea at three planting densities were higher than with sole Napier grass.

The rumen degradability characteristics of treatments studied were presented in Table 7. Accordingly intercropping of lablab and cow pea had a significant effect for all Parameters $(P<0.05)$ except Effective degradability $(P>0.05)$ and Napier grass intercropping with cowpea (T3) at $0.5 \mathrm{~m} \times$ $0.5 \mathrm{~m}$ space has the highest washing loss (rapidly soluble fraction), insoluble but slowly degradation fraction and potential degradability, but has the lowest rate of degradation. It reflected that these treatments had highly degraded materials as energy source and high degraded protein source in the rumen. However, the lowest value recorded for slowly degradable fraction $(b)$ and potential degradability $(a+b)$ in the Napier grass at $1 \mathrm{~m} \times 0.5 \mathrm{~m}$ space without intercropped (T1). Moreover, the effective degradability of each treatment was not significantly $(p>0.05)$.

\section{CONCLUSION}

Napier grass intercropping with lablab and cowpea at different planting densities at Haro sabu Agricultural research center in western Ethiopia has revealed the ability to produce high nutritional quality. The results further indicated that there were improvements of in vitro dry matter digestibility (IVDMD) and in vitro organic matter digestibility (IVOMD) of Napier grass than sole cropping system. Napier grass intercropped with lablab and cowpea at different planting densities had significant effect on the in vitro dry and organic matter digestibility (IVDMD, IVOMD) and increased digestibility. In sacco dry matter disappearances (DMD) and in sacco organic matter degradability (OMD) of Napier grass for many of the incubation hours was relatively higher for the Napier grass intercropping with lablab and cowpea at a planting density of 24 plants $\mathrm{m}^{-2}$ (T7 and T4) respectively. Accordingly, Napier grass intercropped with lablab and cowpea at a planting density of 24 plants $\mathrm{m}^{-2}$ could be a better choice based on forage quantity and quality for the first three months stage of harvest. Therefore to strengthen this research it is advisable to do animal performance trial based on animal feeding practice in order to come up with sound recommendation.

\section{REFERENCES}

Abebe, M. (2007). Nature and Management of Acid Soils in Ethiopia. Haramaya University, Ethiopia.

Albayrak, S., Güler, M. and Töngel, M. Ö. (2004). Effects of seed rates on forage production and hay quality of vetch-triticale mixtures. Asian Journal of Plant Sciences. 3: 752-756.

Albayrak, S. and Türk, M. (2013). Changes in the forage yield and quality of legume-grass mixtures throughout a vegetation period. Turkish Journal of Agriculture and Forestry. 37: 139-147.
Ansah, T., Osafo, E. and Hansen, H.H. (2010). Herbage yield and chemical composition of four varieties of Napier (Pennisetum purpureum) grass harvested at three different days after planting. Agricultural and Biology Journal of North America. 5: $923-929$

AOAC, (1990). Association of Official Analytical Chemists: Official Methods of Analysis of AOAC International. Virginia, USA.

Assefa, G. and Ledin, I. 2001. Effect of variety, soil type and fertiliser on the establishment, growth, forage yield, quality and voluntary intake by cattle of oats and vetches cultivated in pure stands and mixtures. Animal Feed Science and Technology. 92: 95-111.

Asosa Meteorological Agency. (2017). Annual report of the Agrometrological data of the Haro Sabu Agricultural Research Center, Oromia, Ethiopia.

Bayble, T., Melaku, S. and Prasad, N. (2007). Effects of cutting dates on nutritive value of Napier (Pennisetum purpureum) grass planted sole and in association with Desmodium (Desmodium intortum) or Lablab (Lablab purpureus). Livestock Research for Rural Development. 19: 120-136.

Chen, X. (1995). Neway Excel, an Excel application program for processing feed degradability data. International Feed Resources Unit. Rowet research institute. Aberdeen. United Kingdom.

Demissie Negash G.A., Mengistu Urgie and Solomon Mengistu (2017). Chemical Composition and Nutritive Value of Oats (Avena sativa) Grown in Mixture with Vetch (Vicia villosa) with or Without Phosphorus Fertilization in East shoa Zone, Ethiopia. Academic Research Journal of Agricultural Science and Research. 5: 471-479.

Ehlers, J. and Hall, A. (1997). Cowpea [Vigna unguiculata (L.) Walp.]. Field Crops Research. 53: 187-204.

FAO, I. WFP (2015). The state of food insecurity in the world. Meeting the, 2015.

FAO, I. and ISRIC, I. (2012). JRC: Harmonized World Soil Database (version 1.2). FAO, Rome, Italy and IIASA, Laxenburg, Austria.

Fuller, D.Q. (2003). African Crops in Prehistoric South Asia: A Critical Review. Heinrich-Barth-Institute.

Gwayumba, W., Christensen, D., Mckinnon, J. and Yu, P. (2002). Dry matter intake, digestibility and milk yield by Friesian cows fed two Napier grass varieties. Asian Australasian Journal of Animal Sciences. 15: 516-521.

Haro Sabu Agricultural Research Center (HSARC). (2012). Annual report of Haro Sabu Agricultural Research center. Haro Sabu.

Harris, K., Anderson, W. and Malik, R. (2010). Genetic relationships among napier grass (Pennisetum purpureum Schum.) nursery accessions using AFLP markers. Plant Genetic Resources. 8: 63-70.

Hendricksen, R. and Minson, D. (1985). Lablab purpureus: A review. Herbage Abstracts. 55: 215-227.

ILRI, (2010b). Napier or elephant grass ILRI 14984 (Pennisetum purpureum) for livestock feedon small-scale farms. Information leaflet on livestock feeds and feeding technologies for small-scale farmers. Fodder Adoption Project fodderadoption.wordpress.com. 
The Effect of Intercropping of Lablab (Lablab purpureus L.) and Cowpea (Vigna unguiculata L.) at Different Planting...

Islam, M., Saha, C., Sarker, N., Jalil, M. and Hasanuzzaman, M. (2003). Effect of variety on proportion of botanical fractions and nutritive value of different Napier grass (Pennisetum purpureum) and relationship between botanical fractions and nutritive value. Asian Australasian Journal of Animal Sciences. 16: 837-842.

Kandel, R., Singh, H.P., Singh, B.P., Harris-Shultz, K.R. and Anderson, W.F. (2016). Assessment of genetic diversity in napier grass (Pennisetum purpureum Schum.) using microsatellite, single-nucleotide polymorphism and insertion-deletion markers from pearl millet [Pennisetum glaucum (L.) R. Br.]. Plant Molecular Biology Reporter. 34: 265-272.

Kilcher, M. (1981). Plant development, stage of maturity and nutrient composition. Rangeland Ecology and Management/ Journal of Range Management Archives. 34: 363-364.

Klopfenstein, T.J., Mass, R., Creighton, K. and Patterson, H. (2001a). Estimating forage protein degradation in the rumen 1. Journal of Animal Science. 79: E208-E216.

Klopfenstein, T. J., Mass, R., Creighton, K. and Patterson, H. (2001b). Estimating forage protein degradation in the rumen 1. Journal of Animal Science. 79: E208-E216.

Ledgard, S., Giller, K. and Bacon, P. 1995. Atmospheric N2 fixation as an alternative $\mathrm{N}$ source. Nitrogen Fertilization in the Environment. 443-486.

Legesse, G., Small, J.A., Scott, S. L., Kebreab, E., Crow, G.H., Block, H.C., Robins, C.D., Khakbazan, M. and Mccaughey, W.P. (2012). Bioperformance evaluation of various summer pasture and winter feeding strategies for cow-calf production. Canadian Journal of Animal Science. 92: 89-102.

Littell, R.C., Stroup, W.W. and Freund, R.J. (2002). SAS for Linear Models, SAS institute.

Liu, J., Zeng, Z., Jiao, L., Hu, Y., Wang, Y. and Li, H. (2006). Intercropping of different silage maize cultivars and alfalfa. Zuo wu xue bao, 32: 125-130.

Mayer, L., Chandler, D. and Taylor, M. (1986). Lab-lab purpureusA fodder crop for Botswana. Bulletin of Agricultural Research in Botswana. 5: 37-48.

Midmore, D.J. (1993). Agronomic modification of resource use and intercrop productivity. Field Crops Research. 34: 357380.

Mohammeda Semman, G.A., Mengistu Urgeb (2016). Effect of different spacing of Napier grass (Pennisetum purpureum) intercropped with or without Lablab (Lablab purpureus) on biomass yield and nutritional value of Napier grass. Scientific Journal of Pure and Appiled Sciences. 5: 496508.

Morris, J.B. (2009). Morphological and reproductive characterization in hyacinth bean, Lablab purpureus (L.) Sweet germplasm with clinically proven nutraceutical and pharmaceutical traits for use as a medicinal food. Journal of Dietary Supplements. 6: 263-279.

Mucheru-Muna, M., Pypers, P., Mugendi, D., Kung'u, J., Mugwe, J., Merckx, R. and Vanlauwe, B. (2010). A staggered maize-legume intercrop arrangement robustly increases crop yields and economic returns in the highlands of Central Kenya. Field Crops Research. 115: 132-139.
Mullen, C., Holland, J. and Heuke, L. (2003). AGFACTS: Cowpea, lablab and pigeon pea. Edited by Ann Munroe. NSW Agriculture, Orange.

Njoka-Njiru, E., Njarui, M., Abdulrazak, S. and Mureithi, J. (2006a). Effect of intercropping herbaceous legumes with Napier grass on dry matter yield and nutritive value of the feedstuffs in semi-arid region of eastern Kenya. Agricultura Tropica et Subtropica. 39: 260-272.

Oliveira, M. L. F., Daher, R., Figueiredo, E., De Amara Gravina, G., Da Silva, V.B., Rodrigues, E.V., Orio, Shimoya, A., Do Amaral Junior, A.T., Da Silva Menezes, B.R. and Dos Santos Rocha, A. (2014). Pre-breeding of elephant grass for energy purposes and biomass analysis in Campos dos Goytacazes-RJ, Brazil. African Journal of Agricultural Research. 9: 2743-2758.

Orodho, A. (2006). The role and importance of Napier grass in the smallholder dairy industry in Kenya. Food and Agriculture Organization, (Rome) Retrieved August, 24: 2011.

Ørskov, E. and Mcdonald, I. (1979). The estimation of protein degradability in the rumen from incubation measurements weighted according to rate of passage. The Journal of Agricultural Science. 92: 499-503.

Ørskov, E., Reid, G. and Mcdonald, I. (1981). The effects of protein degradability and food intake on milk yield and composition in cows in early lactation. British Journal of Nutrition. 45: 547-555.

Owen, E. and Jayasuriya, M. (1989). Use of crop residues as animal feeds in developing countries. Research and Development in Agriculture. 6: 129-138.

Pasquet, R.S. and Fotso, M. (1994). Répartition des cultivars de niébé [Vigna unguiculata (L.) Walp]. du Cameroun: influence du milieu et des facteurs humains. Journal d'agriculture traditionnelle et de botanique appliquée. 36: 93-143.

Pinkerton, B., (2005). Forage quality. Clemson University Cooperative Extension Service. Forage fact sheet 2. Cooperative Extension Service, Clemson University.

Rengsirikul, K., Ishii, Y., Kangvansaichol, K., Sripichitt, P., Punsuvon, V., Vaithanomsat, P., Nakamanee, G. and Tudsri, S. (2013). Biomass yield, chemical composition and potential ethanol yields of 8 cultivars of napiergrass (Pennisetum purpureum Schumach.) harvested 3-monthly in central Thailand. Journal of Sustainable Bioenergy Systems. 3: 107.

Singh, B.P., Singh, H.P. and Obeng, E. (2013). 13 Elephantgrass. Biofuel Crops: Production, Physiology and Genetics. 271.

Tadesse, T., Liben, M. and Asefa, A. (2012). Role of Maize (Zea mays L.)-Fababean (Vicia faba L.) intercropping planting pattern on productivity and nitrogen use efficiency of maize in northwestern Ethiopia highlands. International Research Journals. 2: 102-112.

Tilley, J.M.A. and Terry, R.A. (1963). A two stage technique for in vitro digestion of forage crops. Journal of British Grassland Society. 18: 104.

Tsubo, M., Walker, S. and Mukhala, E. (2001). Comparisons of radiation use efficiency of mono-/inter-cropping systems with different row orientations. Field Crops Research. 71: 17-29. 
The Effect of Intercropping of Lablab (Lablab purpureus L.) and Cowpea (Vigna unguiculata L.) at Different Planting...

Valenzuela, H. and Smith, J. (2002b). Lablab, Cooperative Extension Service, College of Tropical Agriculture and Human Resources, University of Hawai'i at Mānoa.

Van Soest, P.J. (1994). Nutritional ecology of the ruminant, Cornell University Press.

Wijitphan, S., Lorwilai, P. and Arkaseang, C. 2009a. Effect of cutting heights on productivity and quality of King Napier grass (Pennisetum purpureum cv. King Grass) under irrigation. Pakistan Journal of Nutrition. 8: 1244-1250.

Willey, R. (1979). Intercropping Its Importance And Research Needs Part 1. Competition and Yield Advantages Vol-32. MPKV; Maharastra.

Woodard, K. and Prine, G. (1991). Forage yield and nutritive value of elephantgrass as affected by harvest frequency and genotype. Agronomy Journal. 83: 541-546.
Yellamanda, R., Sankara, R.G., Reddy, Y. and Reddy, G. (2007). Principles of Agronomy, Kalyani Publishers.

Yisehak, K. (2008). Effect of seed proportions of Rhodes grass (Chloris gayana) and white sweet clover (Melilotus alba) at sowing on agronomic characteristics and nutritional quality. Livestock Research for Rural Development. 20: 28.

Zhu, H., Ahmidouch, A., Anklin, H., Arenhövel, H., Armstrong, C., Bernet, C., Boeglin, W., Breuer, H., Brindza, P. and Brown, D. (2001). Measurement of the Electric Form Factor of the Neutron through d'! (e'!, e2 n) p at Q 2= $0.5(\mathrm{GeV} / \mathrm{c})$ 2. Physical Review Letters. 87: 081801. 